\title{
Colloquy
}

\section{NECROPOLITICS VERSUS BIOPOLITICS: \\ Spatialization, White Privilege, and Visibility during a Pandemic}

\author{
CAROLYN M. ROUSE \\ Princeton University \\ (iD) https: / / orcid.org/0000-0002-2343-3306
}

Juxtaposed photos, edited by bricoleurs for commentary, capture two realities. The TikTok posts below show white Americans, protesting against lockdown orders put in place to slow the spread of COVID-19 in the spring of 2020. Their signs read, "Don't cancel my golf season" and "We demand haircuts." These statements of repression contrast with Black protestors carrying signs pleading, "Please don't kill us" and "I can't breathe." The juxtapositions reveal how even proximate experiences with state power are akin to a palimpsest, with stories by white Americans typically effacing those of Black Americans. Placing the experiences side by side, the images reveal ethical and experiential truths otherwise ignored (Levi-Strauss 1974). By unveiling the traces of Black life, the photo collages reveal what has troubled me for a long time with contemporary anthropological critiques of modern states - the overuse of the concept of biopolitics to locate blame within state institutions for just about all forms of human suffering and repression. As responses to the coronavirus have shown, ethical imperatives for how to think and behave are often generated in proximate social spaces (Strong, Trnka, and Wynn 2021, this issue). Theorizing proximity as an ethical problem opens up 


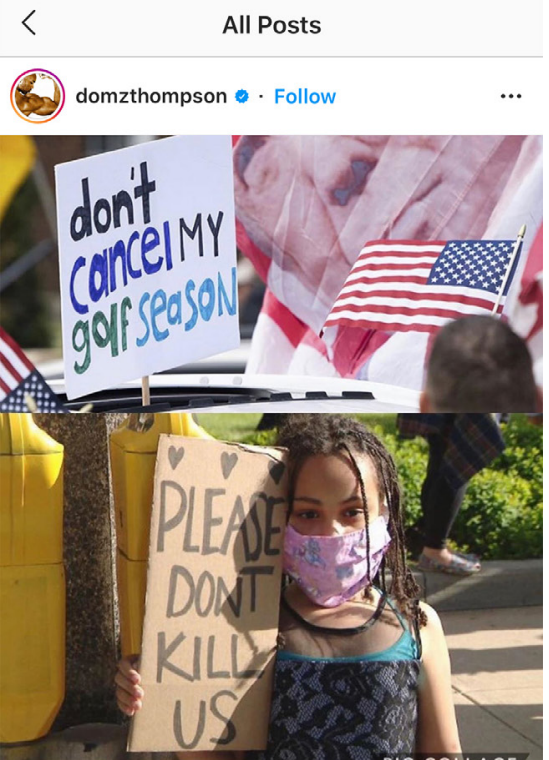

All Posts

\section{$\bigcirc \bigcirc \nabla \ldots$}

44,550 likes

domzthompson I agree @dr.skinshao, sometimes pictures truly speak louder than words. \#Contrast View all 1,100 comments

2 days ago

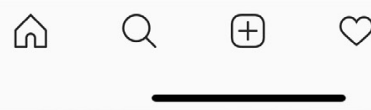

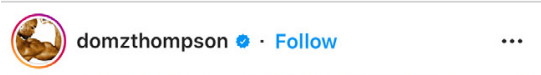
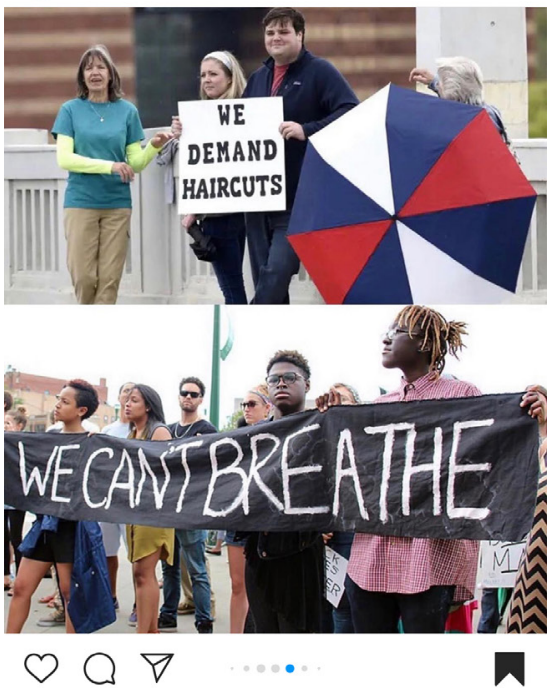

44,550 likes

domzthompson I agree @dr.skinshao, sometimes pictures truly speak louder than words. \#Contrast View all 1,100 comments

2 days ago

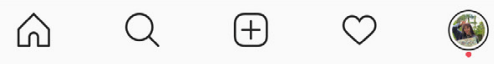

Figure 1. Instagram posts by Dominick Thompson@domzthompson juxtaposing two news images.

for consideration the production and reproduction of cultural racism by proximate nonstate actors.

Michel Foucault's thesis on biopolitics describes the right of the state to decide who lives and who dies, focusing in particular on the regulatory controls and interventions used by states to discipline the body. In The History of Sexuality, Volume I, Foucault $(1984,261)$ states, "One might say that the ancient right to take life or let live was replaced by a power to foster life or disallow it to the point of death." Continuing, he writes that during the seventeenth century in Europe:

The old power of death that symbolized sovereign power was now carefully supplanted by the administration of bodies and the calculated management of life. During the classical period, there was a rapid development of various 
disciplines - universities, secondary schools, barracks, workshops; there was also the emergence, in the field of political practices and economic observation, of the problems of birth rate, longevity, public health, housing, and migration. Hence there was an explosion of numerous and diverse techniques of achieving the subjugation of bodies and the control of populations, marking the beginning of an era of "bio-power." (Foucault 1984, 262)

While useful analytics, biopower and biopolitics are regularly employed by anthropologists as if a direct line between state biopolitical projects and individual experience and behavior were obvious and uncomplicated. In this formulaic use of Foucault, even humanitarian and social aid projects are regularly cast as dehumanizing biopolitics projects, or examples of Giorgio Agamben's (1998) bare life. Rather than cite any particular text, I encourage the reader to go to the AnthroSource search engine and type in "biopolitics" or "biopower" to see how Foucault's theories are stretched to turn pragmatic choices into pernicious biopolitics. ${ }^{1}$

In this facile use of Foucault's important analysis of the modern state, anthropologists often mischaracterize the chosen beneficiaries of state power and surveillance as its victims. For example, to varying degrees most white Americans benefit from biopolitics. Nowhere was this clearer than in three instances in the United States during the first few months of the COVID-19 pandemic. The first instance was the violent arrests of Blacks and Latinx in New York City for not social distancing (Southall 2020). Out of forty arrests in the city, only one person was white. In a tweet, acts of violent racist policing were contrasted with free face mask distribution by the police to mostly white New Yorkers sitting in a park. L. L. Wynn (2021, this issue) describes similar racialized COVID-19 policing in Australia in this Colloquy collection.

The second instance was protests in early May by whites, sometimes heavily armed, challenging the Michigan governor's lockdown order enacted to curb transmission and save lives. The third instance was protests in late May by Blacks, and later multiracial groups, around the continued treatment by police of Black bodies as expendable. Put starkly, whites in May protested against state biopolitics; Blacks protested against state necropolitics (Mbembe 2003).

In theorizing necropolitics, Achille Mbembe (2003) describes how spatialization and colonialization operate together to rule through terror. Rather than trace terror to the biopolitical state, Mbembe describes how individual affect and desire motivate necropolitical acts that blur the boundary between the state and individuals. He uses the example of martyrs and suicide bombers, who kill themselves 
and others based not on the will of a sovereign but what Mbembe $(2003,40)$ calls "the repressed topographies of cruelty." Necropolitics offers a political rationalization for killing available to all, even those who rightly or wrongly feel oppressed.

For four years, I have been conducting fieldwork in a low-income, white rural county in California. My interlocutors are middle-aged white men and women who grew up between the 1950s and 1970s in solidly middle- and upper middle-class households in California's Bay Area. They fell down the economic ladder due to learning disabilities, drug issues, bad luck, or some combination of the three. They call themselves economic refugees because they had to give up their lives in the Bay Area to live in a place with a low cost of living. Their parents, in contrast, were college graduates with high-status jobs in banking, business, and higher education. Unlike their children, they were able to hold onto these jobs, even if they, too, suffered from drug issues and learning disabilities. Structural racism and sexism in the mid-twentieth century meant that their fathers had almost no job competition from people of color, immigrants, or women.

While my interlocutors are classified as "poor" based on their incomes, many inherited family wealth, allowing them to purchase their bungalows or double-wide trailers and to live comfortably with the help of state health insurance, food assistance, and, for some, housing assistance. A few of my interlocutors even used their inheritance to buy rental property that afforded them supplemental income if they were willing to put up with the headache of renting to poor folks, some of whom also suffered from unstable employment and/or drug addiction. One of my interlocutors, himself an alcoholic living with his meth-addicted girlfriend, described the not infrequent arrests of his tenants and property destruction that cost him almost as much as he made in rental income.

Despite having benefited their entire lives from American biopolitics, in the summer of 2016 my interlocutors explained that they were voting for Trump because they felt aggrieved by the Black and Brown people who they claimed took their jobs; jobs they also told me they did not want. While most worked menial jobs, their incomes were barely enough to keep their bellies and gas tanks full, which made their inherited wealth critical to avoiding eviction. Some even made money off of renters who lived with them in their trailers or bungalows. My interlocutors also rejected President Obama's Affordable Care Act (ACA) health insurance even though, in some cases, the ACA had saved their lives. They voted for policies to dismantle the social safety nets as an act of defiance against biopolitics, or as they described it, "the Nanny State." They were protesting biopolitics in ways akin to whites protesting COVID-19 lockdowns. 
To describe the Black American experience, Mbembe's thesis on necropolitics proves more useful than biopolitics. Blacks have been at the receiving end of necropolitics generated by white slave owners, segregationists, business owners, clergy, and doctors. Whites have acted independently of the state to make survival for Blacks difficult, and the U.S. government has often been forced to assert the legal rights of Black Americans against the desires of white segregationists and white supremacists. Some might call a hospital's refusal to treat Black patients, or a bank's refusal to offer loans to Black customers, "state-sponsored" racism or violence. But it is not always clear if the violence is being led by the state or by people who genuinely believe in Black inferiority.

This ready-made use of biopolitics as a critique of the state results from the lack of attention to what has been described as a veil: a veil that shapes Black people's experiences in ways that white Americans rarely understand (Du Bois 1989). Blacks on one side of the veil work especially hard to prove their humanity to the shopkeepers, police, educators, and medical professionals on the other side. But even proving one's right to occupy space can be difficult, as we saw in the case of the teenager Trayvon Martin, killed by a stranger who felt Martin must not belong in a middle-class subdivision. For many whites, Blacks remain frightening, undifferentiated, veiled silhouettes that threaten order.

Whites, who are considered rational and worthy of empathy, live on the side of the veil where the state tries to foster life; Blacks live on the other side, where the state disallows life. Ignoring this veil allows scholars to critique everything from public health to humanitarianism without attending to whether states or institutions are motivated, in a particular instance, to protect an interlocutor's life or treat it as expendable. This difference is critical. My argument has been that Black Americans would love to be subjects of biopolitical regulatory controls if they were to receive quality health care, education, and legal and social rights equal to those of white citizens. To be treated as a rational contributor to modern state projects means to be treated as human. New Zealand's response to COVID-19 provides a case in point (Trnka 2020).

Biopolitics and biopower can be pernicious when, for example, the state claims that eugenics, unethical medical experimentation, or deregulating polluting chemicals in the name of job creation fosters quality of life. Biopolitics continues to be a critically important analytic, particularly with respect to how the state disciplines what it perceives as unruly bodies and behaviors (see Strong 2021, this issue; Levine and Manderson 2021, this issue). I do not celebrate biopolitics as good governance, I just reject unreflexive, antibiopolitical theorizing. Cheekily, I might 
say that I am anti-antibiopolitics (with respect to Clifford Geertz [1984]). Bodies are subjugated in the process of acculturation, which means that biopolitics is as essential to culture as sex, labor, and food. This is why attributing suffering to biopolitics only takes us so far analytically. More important is tracing how and why people participate in their own subjugation for good (think evidence-based medicine) or bad (think war on drugs). Biopolitical analyses rarely help us understand why certain groups are targeted for racialization and exclusion, while others are not.

My colleagues have treated my pragmatic appreciation for biopolitics and biopower as an oddity. But as a scholar of race and institutions, I am constantly reminded that biopolitical states fostering life remain necessary for Black survival and flourishing. In a libertarian state, or James C. Scott's (2010) theorized anarchic state, Black Americans would find themselves at the whim of powerful individuals who would likely see them as unworthy of health, education, or improved quality of life. And there are historical examples - from slavery to convict leasing to mass incarceration. Blacks live on the side of the veil where one's life is expendable unless one fights to be recognized as human.

This veil became especially clear on January 6, 2021, when a mob of mostly white Americans seditiously attacked the U.S. Capitol Building to stop the certification of President Biden's Electoral College win. Media commentators noted how, compared to the mass arrests and police violence inflicted on Black Lives Matter protestors, the white terrorists were essentially allowed to rampage the Capitol unimpeded. White privilege on full display. The ethical calculus made by the security spoke volumes about how state biopolitical projects differ radically for Black versus white bodies.

\section{CONCLUSION}

Experience tells us that proximity to others comes with forms of cultural belonging, shared ethical beliefs, and moral practices. What COVID-19 has demonstrated is that despite proximity, Black Americans remain on the other side of a veil most white Americans have trouble discerning. The virus has exposed how people, living side by side, can have radically different experiences with state and institutional power. In the United States, the killings of unarmed Blacks by police, racial health inequities reflected in COVID-19 death rates, and the impunity granted violent white nationalists have made visible these fault lines between a biopolitical system set up to care for whites and a necropolitical system that treats Black bodies as expendable, useful only for labor. This inequity is clearly exem- 
plified in the continued mass incarceration of Black "addicts," compared with the medicalized treatment of whites identified as having a "drug-use disorder." How are these same whites also victims of biopolitics and biopower? And through their enforcement of social codes at the level of the everyday, white beneficiaries are also ersatz, not actual, state actors, policing the schools, public spaces, neighborhoods, and businesses to make sure Blacks are not receiving more than those with power and wealth feel they should.

COVID-19 not only unveiled the hidden text of Black life but also revealed something about our discipline. Importantly, how have anthropologists come to theorize the state so narrowly from the vantage of people with privilege who may feel disadvantaged by state structures that actually protect their health, wealth, education, physical safety, and legal status? Where did such a unidirectional understanding of state power come from? Anthropologists have come a long way in terms of decolonizing our discipline, but we still have room to grow in terms of theorizing the experiences of marginalized others. We need to develop theoretical tools to understand the complexities of power and authority and to not confuse cultural proximity with common experience.

\begin{abstract}
Anthropologists have used Michel Foucault's thesis on biopolitics to critique modern institutions. Yet while useful, biopolitics is often misapplied. The arrests, killings of unarmed Blacks by police, COVID-19 racial health inequities, and the January 6 white nationalist act of sedition made visible fault lines between a biopolitical system set up to care for whites and a necropolitical system that treats Black bodies as expendable. By critiquing the facile overuse of biopolitics and biopower, this article also speaks to what COVID-19 uncovered within the academy. [biopolitics; necropolitics; pandemic; protests; race; United States]
\end{abstract}

\title{
NOTES
}

1. See https://anthrosource.onlinelibrary.wiley.com/.

\section{REFERENCES}

Agamben, Giorgio

1998 Homo Sacer: Sovereign Power and Bare Life. Translated by Daniel Heller-Roazen. Stanford, Calif.: Stanford University Press.

Du Bois, W.E.B.

1989 The Souls of Black Folk. New York: Bantam Classics.

Geertz, Clifford

1984 “Anti Anti-Relativism.” American Anthropologist 86, no. 2: 263-78. https://www. jstor.org/stable/678960. 
Foucault, Michel

1984 The Foucault Reader. Edited by Paul Rabinow. New York: Pantheon Books.

Levi-Strauss, Claude

1974 The Savage Mind. 2nd ed. London: Weidenfeld and Nicholson.

Levine, Susan, and Lenore Manderson

2021 "Proxemics, COVID-19, and the Ethics of Care in South Africa." Cultural

Mbembe, Achille Anthropology 36, no. 3: 391-99. https://doi.org/10.14506/ca36.3.06.

2003 “Necropolitics." Translated by Libby Meintjes. Public Culture 15, no. 1: 11-40. https://muse.jhu.edu/article/39984.

Scott, James C.

2010 The Art of Not Being Governed: An Anarchist History of Upland South Asia. New Haven, Conn.: Yale University Press.

Southall, Ashley

2020 "Scrutiny of Social-Distance Policing as 35 of 40 Arrested Are Black." New York Times, May 7. https://www.nytimes.com/2020/05/07/nyregion/nypd-social-

Strong, Thomas distancing-race-coronavirus.html.

2021 "The End of Intimacy." Cultural Anthropology 36, no. 3: 381-90. https://doi. org/10.14506/ca36.3.05.

Strong, Thomas, Susanna Trnka, and L. L. Wynn

2021 "'Lenfer, c'est les autres': Proximity as an Ethical Problem during COVID-19." Cultural Anthropology 36, no. 3: 341-49. https://doi.org/10.14506/ca36.3.01.

Trnka, Susanna

2020 "Rethinking States of Emergency." Forum on COVID-19 Pandemic, Social Anthropology 28, no. 2: 367-68. https://doi.org/10.1111/1469-8676.12812.

Wynn, L. L.

2021 "The Pandemic Imaginerie: Infectious Bodies and Military-Police Theater in Australia." Cultural Anthropology 36, no. 3: 350-59. https://doi.org/10.14506/ ca36.3.02. 